UDK 811.124'36“15“

27-789.5Alvarez, M.

811.124’36:811.163.42’36]“15/17“"

https://doi.org/10.31337/oz.75.1.4

Izvorni znanstveni rad

Primljeno: 9.5.2019.

Prihvaćeno: 22.1.2020..

\title{
The Jesuit Syllabus vocabulorum of Alvares' Grammar in Croatian Editions
}

\author{
Ivana Kresnik*, Vladimir Horvat**
}

\begin{abstract}
Summary
In the late 16th century, German Jesuits prepared a methodical handbook for their students to help them master differences in gender between Latin words and synonymous German words, as well as other difficult sections in Latin grammar. The handbook was first published under the title Vocabula Grammaticae Emmanuelis Alvari (1584) and later as Syllabus (Omnium) Vocabulorum Grammaticae Emmanuelis Alvari. This paper describes the chronology and content of the handbook and compares it to Croatian editions from 1726 and 1735 which are attributed to Juraj Habdelić and Andrija Jambrešić, as well as to Mikloušić's handbook of the same title.
\end{abstract}

Key words: Syllabus Vocabulorum; Vocabula Grammaticae; Jesuit schooling; Manuel Alvares; Juraj Habdelić; Andrija Jambrešić; Tomaš Mikloušić

\section{Introduction}

The Portuguese Jesuit Manuel Álvares (1526-1582) published a Latin grammar in 1572 titled De Institutione Grammaticae Libri Tres. In 1599, the Ratio studiorum declared it the standard school grammar for Jesuit schools (cf. Ratio studiorum, 1603). Álvares' Grammar has since been published in a few hundred different editions across the world, from Europe to Japan (Kemmler, 2015), either in the original, translated, or revised form.

The German Jesuits created an additional handbook for students, who had not yet learned Latin, which was published in multiple editions beginning in 1594 as Vocabula Grammaticae Emmanuelis Alvari or Syllabus (Omnium) Vocabulorum Grammaticae Emmanuelis Alvari. Four editions had been published for Croatian-speaking lands by the turn of the 19th century, entitled Syllabus Vocabulorum Grammaticae Emmanuelis Alvari.

* Ivana Kresnik, Ph.D., Senior Assistant Professor, Faculty of Croatian Studies, University of Zagreb. Borongajska cesta 83d, 10000 Zagreb, Croatia. E-mail: ikresnik@hrstud.hr

** Vladimir Horvat, Ph.D., Retired Professor, Faculty of Philosophy of the Society of Jesus, University of Zagreb, Jordanovac 110, 10000 Zagreb, Croatia. E-mail: vhorvat9@gmail.com 
The goal of this paper is to describe Vocabula/Syllabus (Omnium) Vocabulorum Grammaticae Emmanuelis Alvari and within this context, to portray the circumstances and goals behind its publication for Croatian-speaking lands. As some previous research has linked Juraj Habdelić and Andrija Jambrešić to the 1726 and 1735 Croatian editions of the Syllabus Vocabulorum, the paper will give an analysis of the share each may have had in their publication. A separate section is dedicated to Mikloušić's 1796 and 1817 editions of the Syllabus Vocabulorum.

\section{Syllabus vocabulorum of Álvares' Grammar}

After its initial publication, many editions of Álvares' Latin Grammar quickly spread throughout Jesuit gymnasiums: "Jesuit schools most often used textbooks which had already been recognised throughout the world. Hence, for example, for studying Latin, the Grammar of the Portuguese Jesuit Emmanuel Alvares [...] was used and it was reprinted over 400 times out of which 16 editions were printed in Zagreb."1 In the year that it was published (1572), it also was published in Rome and Dillingen an der Donau as well as two editions in Lisbon. By the end of the 16th century, nearly one hundred editions, revisions, or translations had been published (GHTC, s. a.). In 1599 it was listed in the Ratio studiorum as the official Latin Grammar Handbook for Jesuit schools (Ratio studiorum, 1603; Carvalh, 2001). The German Jesuits prepared a separate short methodical handbook for their students to help them master a difficult chapter in Álvares' Grammar dealing with the problem of gender; more than ten editions of this handbook were published under the title Syllabus (Omnium) Vocabulorum Grammaticae, Emmanuelis Alvari or Vocabula Grammaticae.

The oldest edition of this handbook is known only as a bibliographic citation, which shows that the Vocabula Grammaticae was published in 1594 in Lyon (Lugdunum) in duodecimo format $\left(12^{\circ}\right)$ (Machado, 1752, 171). This same information is found in a list of works related to Álvares' Grammar in a Parisian edition of the Grammar (Alvares, 1859, VIII). It is unknown whether any copies of this edition have survived, however an edition with the same title was published in 1626 and is mentioned in multiple bibliographies; the content of the 1758 (Wirceburgi) edition bearing this title corresponds to editions of the Syllabus (Omnium) Vocabulorum.

The full title of the book published in Augsburg is: Syllabus Omnium Vocabulorum Grammaticae, Emmanuelis Alvari, de Societate Iesu, In nostram Vernaculam conuersorum cum Formis comparandi inflectendique nomina Adiectiua per omnes casus et genera. Quibus accesere componendi regulae et ortographia, ex Aldo

1 »Isusovačke škole su najčešće upotrebljavale udžbenike koji su već bili priznati širom svijeta. Tako je npr. za učenje latinskoga jezika služila gramatika portugalskog isusovca Emmanuela Alvaresa [...] koja je doživjela preko 400 izdanja, a od toga je u samom Zagrebu bila tiskana 16 puta (Horvat, 1989, 19). 
Paulli F. et aliis in gratiam Latinae linguae tironum collecta ("A list of all words in the Grammar of Manuel Álvares in our [German] colloquial language, with comparative forms and declinations of adjectives for all cases and genders"). This is a dictionary-type handbook in which Latin words are translated into the language of the students being taught. This first available edition from 1610 was compared with the oldest complete edition of Álvares' Grammar (Alvarus, 1598). The German handbook begins with the chapter De generibus nominum, quae ex significatione cognoscuntur, with the words: vir, Cato, leo, scriba, lanista, scurra, rabula, lixa, cacula, nauta, bibliopola, praedo, comedo, consul, tubicen, tibicen, vas, verres, aries, aedilis, praes etc. (Syllabus, 1610, 1-28). These words are found in the chapter titled De generibus nominum difficilioribus, however the order is not entirely the same (Alvarus, 1598, 122-138). The German edition then continues with the chapter De nominum declinatione (Syllabus, 1610, 28-51), which lists words from the grammatical chapter De nominum declinatione (Alvarus, 1598, 138-152). The list of words in the chapter De verborum praeteritis et supinis (Syllabus, 1610, 5181) relates to the grammatical chapter De praeteritis et supinis verborum (Alvarus, 1598, 152-168). Thus, the first 81 pages of the German handbook Syllabus Omnium Vocabulorum (Syllabus, 1610) relate to the second half of the first Grammar book, titled De generibus nominum et declinationibus atque verborum praeteritis, libri huius: Pars altera (Alvarus, 1598, 122-168). The words in it are not listed in alphabetical order, instead they follow the Latin language teaching method.

The German handbook featured an additional chapter titled De grammatica, et partibus eius (Syllabus, 1610, 82-86) which explained basic grammatical terminology in Latin. This was followed by a chapter titled Ortographia ex Aldo Manutio Paulli filio, Theodoro Pulmanno, et Simone Verrepaeo collecta, discussa et aucta (Syllabus, 1610, 87-90). Another additional chapter titled Formae comparandi, inflectendique nomina adiectiva per omnes casus, et omnia genera (Syllabus, 1610, 91-117) was included as a separate section with its own title page, but with pagination that followed the preceding section of the book.

Since part of the title reads in nostram vernaculam without any indication of the language it refers to, one may conclude that the compilers of this handbook did not expect it to be eventually translated into other languages. The handbook was exceptionally popular in German-speaking countries, and by the end of the 18th century, dozens of editions had been published. However, in 1713 an edition appeared for the Hungarian and Slovak languages (Syllabus, 1713), likely the first edition for the non-German-speaking world. It was certainly highly useful, as four other subsequent Hungarian-Slovak editions in the same form have also been found (1717, 1731, 1733, and 1759).

The next non-German edition was the Croatian Syllabus Vocabulorum Grammaticae [...] in Illyricum sive Croatis et Sclavonibus vernaculam conversorum (Syllabus, 1726). It was followed by a Hungarian-German edition (Syllabus, 1731), a Hungarian-Slovak edition (Syllabus, 1733), and another Croatian edition (Syllabus, 1735). It is somewhat surprising to note that a German-Italian edition (Syllabus, 1681-1728) and a German-French edition (Syllabus, 1742) were also 
published. The order of the content and words in all of these editions correspond to the 1610 edition, with the exception of the chapter titled Formae, which was lacking some editions from the early 17 th century onwards. There is a possibility that some other non-German editions may exist which were not available to us before this paper was submitted. Tomaš Mikloušić also published a Croatian edition titled Syllabus vocabulorum Grammaticae [...] in Croaticam linguam conversorum, first in Zagreb in 1796 and again in 1817 in Budapest. The following section of this paper will describe the history of the Croatian editions.

\section{The Croatian editions from 1726 and 1735}

Bibliographies and library catalogues attest to the fact that two editions titled Syllabus Vocabulorum Grammaticae Emmanuelis Alvari è Societate Jesu: In Illyricam, sive Croatis et Sclavonibus vernaculam conversorum were published for Croatian-speaking lands in 1726 and 1735 . Understandably, these editions have not attracted the particular attention of linguists, as they are nothing more than peripheral auxiliary handbooks and provide no important linguistic data.

On the basis of Šafaŕik's manuscript heritage, Jiriček stated that the author of the 1726 and 1735 Syllabus was Andrija Jambrešić: ${ }^{2}$ »Syllabus vocabulorum Grammaticae in Illyricam translatus cum appendice generum, declinationum Emanuelis Alvari (auctore Andrea Jambressich). Zagrabiae, typis Jo. Barthol. Pallas 1726. $8^{\circ}$. - Ib. typ. J. Weitz 1735. $8^{\circ}$. Die zweite Ausgabe u. d. T.: Em. Alvari Syllabus vocabulorum Grammaticae in Illyricam vernaculam conversorum (auct. Andr. Jambressich). Zagr. typ. J. Weitz 1735. $8^{\circ}$ « (Šafař́k, 1865, 316).

In 1912 Vladoje Dukat dedicated an entire paper to the 1726 publication. Later research often takes Dukat's conclusions as given fact. Dukat reports that Kukuljević mentions the 1726 Syllabus as Habdelić's second linguistic work (after his ${ }^{3}$ Dictionar), as well as the fact that Šafarik attributes the same work to Andrija Jambrešić. Dukat invested a great deal of effort into determining whether the author was Habdelić or Jambrešić. Namely, he compared the Syllabus with

2 Andrija Jambrešić SJ (Andreas Jambressich, 1706-1758), Croatian lexicographer. He taught philosophy, theology, and canonical law at Jesuit high schools in Zagreb, Nova Gorizia, and Trnava. His best-known lexicographic work is Lexicon latinum (Zagreb, 1742), a Latin-Croatian-German-Hungarian dictionary. He was also active in the community in other spiritual and leadership capacities: as the head of the large student congregation in Zagreb and as the regent of the Zakmardi seminary. For example, it has been noted that he had a valuable water pump installed in this capacity in 1738 (Vanino, 1987, 412).

3 Juraj Habdelić SJ (Juraj Habdelich, 1609-1678), Croatian theological writer, preacher, and lexicographer. He published the moral and educational works Zerczalo Marianzko (Graz, 1662) and Pervi Otcza nassega Adama greh (Graz, 1674). Although he regularly preached at Zagreb's St. Mark's Church, as opposed to other productive 17 th- and 18th-century preachers, he did not publish a collection of his sermons; instead, he wrote spiritual and educational works that could serve anyone on any occasion. His third literary work of a religious character, Duše verne, has not survived. He was so greatly revered as a preacher in his time that the church bells of Zagreb tolled for two days after his death (Bratulić, 1989, 4-7). 
Habdelić's Dictionar and Jambrešić's Lexicon. He used a numerical method to arrive at the conclusion that Habdelić worked on the book, and that 20-year-old Jambrešić helped him with the publication thereof: "I must therefore repeat my hypothesis, which I mentioned briefly in the aforementioned work: it is in fact somewhat unbelievable that a twenty-year-old youth (Jambrešić was 20 years old in 1726) could have produced such a work, but it is possible that Jambrešić in his formative years had a certain contact with the printing trade and the editions of Habdelić's manuscript, and that the idea of attributing authorship to him stemmed from this conjecture" (Dukat, 1912, 104). ${ }^{4}$ The claim regarding Habdelić's or Jambrešić's supposed authorship which was made in academic research has also entered encyclopaedic publications: "Sillabus vocabulorum [...] the literature notes that possible authors of this work are J. Habdelić and A. Jambrešić" (Nemec, 2000, s. v. Habdelić, Juraj). ${ }^{5}$

The account on the history of the Syllabus in the first section of this paper makes it clear that neither Habdelić nor Jambrešić could have been the authors. Dukat could have saved himself a great deal of effort had he first checked for similar previous editions. This deficiency can be justified by the fact that it was much more difficult to find such information in Dukat's time than it is today. However, even without these modern conveniences, it is clear that no Jesuit would have claimed authorship of a work that was not his.

To ensure that this version is only a reworked German Syllabus, we shall provide a comparative transcription of the first page of the oldest available German edition from 1610 and the Croatian edition from 1726.

\begin{tabular}{|c|c|}
\hline $\begin{array}{l}\text { 1610. Syllabus Omnium Vocabulorum } \\
\text { Grammaticae, Emmanuelis Alvari, } \\
\text { de Societate Iesu, In nostram } \\
\text { Vernaculam conuersorum. Augustae } \\
\text { Vindelicorum: Apud Chrysostomum } \\
\text { Dabertzhofer. }\end{array}$ & $\begin{array}{c}\text { 1726. Syllabus Vocabulorum } \\
\text { Grammaticae Emmanuelis Alvari è } \\
\text { Societate Jesu: In Illyricam, sive Croatis } \\
\text { et Sclavonibus vernaculam conversorum. } \\
\text { Zagrabiae: Typis Joannis Bartholomaei } \\
\text { Pallas. }\end{array}$ \\
\hline $\begin{array}{l}\text { DE GENERIBUS NOMINUM, } \\
\text { QUAE EX SIGNIFICATIONE } \\
\text { COGNOSCUNTUR } \\
\text { Quae Maribus solum. } \\
\text { Vir, genitiu, viri. ein Mann. } \\
\text { Cato, onis. nomen proprium viri. } \\
\text { Leo, onis. ein Löwe. } \\
\text { Scriba, ae. ein Schreiber. }\end{array}$ & $\begin{array}{l}\text { DE GENERIBUS NOMINUM } \\
\text { QUAE EX SIGNIFICATIONE } \\
\text { COGNOSCUNTUR } \\
\text { Quae Maribus solum. } \\
\text { Vir, gen: viri. Mush, Chlovek, Muska glava. } \\
\text { Cato, onis. nomen proprium viri. } \\
\text { Scriba, ae. Pifzec, Pijzár. } \\
\text { Lanista, ae. Bodesnik. }\end{array}$ \\
\hline
\end{tabular}

4 »Stoga smijem ovdje ponoviti hipotezu, koju sam onako uzgred kazao u pomenutoj raspravi: da je doduše ponekuda nevjerojatno, da bi dvadesetogodišnji mladić (g. 1726. bilo je Jambrešiću 20 godina) izradio ovakovo djelo, ali da je moguće, da se Jambrešić starao oko štampe i izdanja Habdelićeva rukopisa, pa da se odavde zarodila misao o njegovu autorstvu « (Dukat, 1912, 104).

5 »Sillabus vocabulorum [...] u literaturi se kao mogući autori ovog djela navode i J. Habdelić i A. Jambrešić« (Nemec, 2000, s. v. Habdelić, Juraj). 


\begin{tabular}{l|l|} 
Lanista, ae. ein Fechrmeister. & Lanista, ae. Bodesnik. \\
Scurra, ae. ein Speyvogel. & Scurra, ae. Szpotlyevecz, neszramni falecz. \\
Rabula, ae. ein Schwetzer. & Lixa, ae. Kuhtich Kuhta. \\
Lixa, ae. ein Sudelkoch. & Nauta, ae. Brodar, Mornar. \\
Cacula, ae. ein Trossbueb. & Bibliopola, ae. Knigar. \\
Nauta, ae. ein Schiffman. & Praedo, onis. Tolvai Razboinik. \\
Bibliopola, ae. ein Buechführer. & Comedo, onis. Lakomécz Jedecz \\
Praedo, onis. ein Strassrauber. & Posdërdecz. \\
Comedo, onis. ein Fresser / Prasser. & Consul, lis. Szvetnik veliki. \\
Consul, lis. ein Burgermeister. & Tubicen, nis. Trumbetas. \\
Tubicen, inis. ein Trommeter. & Tibicen, nis. Sipus. \\
Tibicen, inis. ein Schwegelpfeiffer. & Vas, adis. Poruk ali Jemecz za \\
Vas, adis. ein Bürg. & drugoga. \\
Verres, ris. ein Eber. & Verres, is. Neroztecz. \\
Aries, ietis. ein Bider. & Aries, is. Oven, Brav. \\
Aedilis, is. ein Brawmeister. & Aedilis, lis. Sikutor. \\
Praes, dis. ein Bürg. & Praes, dis. Poruk ali Jemecz za drugoga. \\
& Arabs, bis. Harapin, Harap. \\
& Thrax, cis. Drinopolyecz. \\
& Rex, gis. Kraly.
\end{tabular}

This is clearly the same work, with the German part translated into Croatian. A copy of the 1726 edition is kept at the National and University Library in Zagreb. The library catalogue mistakenly notes that this copy is from 1735, and that the copy from 1726 is only a bibliographic entry. Actually, the reverse is true: the library has the 1726 edition, while the 1735 edition is a bibliographic entry from multiple sources.

\section{Mikloušić's edition}

After completing his studies in philosophy at the Zagreb Academy and a fouryear theology programme in Budapest, Tomaš Mikloušić served his first Mass, as tradition required, in his birthplace of Jastrebarsko on January 12, $1791 .{ }^{6} \mathrm{He}$ served as chaplain in Jastrebarsko, and later in Stenjevec. In November of 1795, he was elected to the position of professor of Latin grammar at the Zagreb Archigymnasium, which he held for four years (Cesarec, 2009, 149).

This time period is the subject of our interest, since it was during the time that he was a professor of grammar that he prepared and published the 1796 Syllabus vocabulorum Grammaticae Emmanuelis Alvari, in Croaticam linguam converso-

6 Tomaš Mikloušić (Thomas Miklòufsich, 1767-1833) was a diocesan priest and one of the most productive writers of northwestern Croatia. He made major contributions to general cultural and spiritual literature. The Society of Croatian Writers organised an academic conference dedicated to Mikloušić on December 12, 2017 in honour of the 250th anniversary of his birth, at which Alojz Jembrih, Ivana Kresnik, and Marijana Borić held speeches. 
rum (Zagreb: Typis Novoszelianis), which was also his first printed publication. A second edition of this same book was published in 1817 (Budapest: Typis Regiae Universitatis). The year 1796 was a turning point for the diocesan printing house, since Zagreb Bishop Maksimilijan Vrhovac had to give it up, signing it over instead to his brother-in-law, Antun Novosel. That year, the printing house printed seventeen publications (Deželić, 1925, 112), including Mikloušić's Syllabus vocabulorum.

Mikloušić included a brief preface to this edition, which is an important source of information: " "The usefulness of and need for this book will be evident upon reading it. More than fifty years ago, a similar book was published for the Croatian people, but in the old-fashioned manner. Now, it is organised differently and has been adapted to the Croats of today. With all my heart I wish this to be a demonstration to you of my efforts and work, native sons, enthusiasts of the Latin and Croatian languages! Your progress shall be the reward for my efforts. May you enjoy good health! Zagreb, 1 March 1796."

Mikloušić mentions in this preface that a similar book had been published more than fifty years earlier, certainly referring to the 1735 Syllabus vocabulorum, which was prepared in "the old-fashioned manner". He stresses that his book was prepared in a different, adapted form. His meaning becomes clear when we compare the first page of the 1610 edition to the first page of Mikloušić's 1796 edition.

\begin{tabular}{|c|cc|}
\hline $\begin{array}{c}\text { 1610. Syllabus Omnium Vocabulorum } \\
\text { Grammaticae, Emmanuelis Alvari, } \\
\text { de Societate Iesu, In nostram } \\
\begin{array}{c}\text { Vernaculam conuersorum. Augustae } \\
\text { Vindelicorum: Apud Chrysostomum }\end{array}\end{array}$ & $\begin{array}{c}\text { 1796. Syllabus vocabulorum } \\
\text { grammaticae Emmanuelis Alvari, } \\
\text { in Croaticam linguam conversorum. } \\
\text { Zabrabiae: Typis Novoszelianis. }\end{array}$ \\
\hline DE GENERIBUS NOMINUM, & & \\
QUAE EX SIGNIFICATIONE & Réchih Diàchkeh, koje vu fzlovniczi \\
COGNOSCUNTUR & \multicolumn{3}{|c|}{ Znamenuvanye } \\
Quae Maribus solum. & Grammatiki Diàchki potrebujufze. \\
Vir, genitiu, viri. ein Mann. & Littera & Szlova. \\
Cato, onis. nomen proprium viri. & Syllaba & Szlovka. \\
Leo, onis. ein Löwe. & Vocalis & Szamoglafznik. \\
Scriba, ae. ein Schreiber. & Consonans & Zkupglafznik. \\
\hline
\end{tabular}

7 Emphasis added. »Knifice ove hafzen i potrebochu chtenye kazalo bude. Pred petdefzetemi i viffe leti spodobna, nego namerom na fztarinzku Emmanuela Alvari Slovinczu, na fzvetlo je iziflla. Vezda vu drugachkom Pokazu sadaffni Slovinczi prilagodyena van daje se. Trud i pofzel, kojega imal sem, vam, domorodni Szini! diachkoga i horvatzkoga jezika lyubiteli! serdcheno prikafujem. Napredek vas bude zadovoljna placha truda mojega, zdravi ostanete. Dajem v Zagrebu dan 1vi maloga travna 1796.« 


\begin{tabular}{|c|c|c|}
\hline $\begin{array}{l}\text { Lanista, ae. ein Fechrmeister. } \\
\text { Scurra, ae. ein Speyvogel. } \\
\text { Rabula, ae. ein Schwetzer. } \\
\text { Lixa, ae. ein Sudelkoch. } \\
\text { Cacula, ae. ein Trossbueb. } \\
\text { Nauta, ae. ein Schiffman. } \\
\text { Bibliopola, ae. ein Buechführer } \\
\text { Praedo, onis. ein Strassrauber. } \\
\text { Comedo, onis. ein Fresser / Prasser. } \\
\text { Consul, lis. ein Burgermeister. } \\
\text { Tubicen, inis. ein Trommeter. } \\
\text { Tibicen, inis. ein Schwegelpfeiffer. } \\
\text { Vas, adis. ein Bürg. } \\
\text { Verres, ris. ein Eber. } \\
\text { Aries, ietis. ein Bider. } \\
\text { Aedilis, is. ein Brawmeister. } \\
\text { Praes, dis. ein Bürg. }\end{array}$ & $\begin{array}{l}\text { Nomen Ime. } \\
\text { substantivum } \\
\text { adjectivum } \\
\text { proprium } \\
\text { appellativum } \\
\text { collectivum } \\
\text { interrogativum } \\
\text { relativum } \\
\text { redditivum } \\
\text { possessivum }\end{array}$ & $\begin{array}{l}\text { Szamoztavno. } \\
\text { pridavno. } \\
\text { laztovito. } \\
\text { obchinzko. } \\
\text { zkupno. } \\
\text { pitajùche. } \\
\text { zpomnyivo. } \\
\text { odgovorno. } \\
\text { làdavno. }\end{array}$ \\
\hline
\end{tabular}

Mikloušić actually created his own original version of the Syllabus, relying thereby on the entirety of Álvares' Grammar. He begins with grammatical terminology, which he introduces on the first five pages; however, throughout the remainder of the book he explains this grammatical terminology extensively (cf. Jembrih, 2004; Jembrih, 2018). This is followed by words from the first declination: musa, ae; filia, ae; dea, ae; famula, ae; anima, ae; domina, ae, etc. Examples for all declinations of nouns are followed by a chapter with lists of adjectives. All other grammatical chapters are dealt with in order.

Mikloušić, the fairly young and apparently highly motivated grammar professor, created an entirely new methodical handbook, which had only the title in common with the previously described German handbook. The difference is also evident in the number of pages. The original Syllabus vocabulorum most often did not exceed 96 pages ( 8 duodecimos), while Mikloušićs work was published on 217 pages (27 octaves) using a different folio size. Mikloušić was certainly aware of the difference in relation to the original Syllabus, however he believed that this design for the handbook would make it more appropriate for use in the teaching environment of that time. Bishop Vrhovac published this handbook in his publishing house, which could signify that it had been ordered for the Archigymnasium. Mikloušić ends the book with the following statement: "Let this be enough for now. In time, I will do even more to serve my students." ${ }^{8} \mathrm{He}$ followed through on this statement, becoming one of the most active, most productive writers of northwestern Croatia.

8 »Ova fzada naj budeju zadozta. Z-vrémenom viffe za hafzen mojeh Vucheníkov vuchiniti felím. Dájem v-Zagrebu dan 1vi Velikoga Trávna.« 


\section{Conclusion}

The Syllabus Vocabulorum of Álvares' Grammar was originally intended for German students to use to master differences in gender between Latin words and synonymous German words. Regardless of the small differences in titles or later accommodations to different languages, all editions of the Syllabus share the same order of chapters and words as are found in the 1610 edition. The content was related only to the second chapter of the first book of Álvares' Grammar. In the early 18th century, this handbook was published in versions for Hungarian, Slovak, Croatian, Italian, and French, always respecting the original concept, which was created by German Jesuits in the late 16th century. Jesuits from Zagreb adapted it to the Croatian language and published it in 1726, and again in 1735. This adaptation could have technically been done by any one of the Jesuit fathers, and it is clear that none of them would have signed it as his own original work. In 1976, Tomaš Mikloušić published his handbook under the title Syllabus vocabulorum, which does not follow the original idea of the Jesuit Syllabus; instead, it represents Mikloušić's own original methodical handbook for use in mastering Álvares' Grammar in its entirety. Aside from Mikloušić's original publication, the Syllabus vocabulorum of Álvares' Grammar was published in several dozen editions from the first known edition in 1594 until the mid-19th century; of these, forty-six were found by the time of the publication of this work, either as entire books or as bibliographic citations.

\section{Syllabus vocabulorum editions list ${ }^{9}$}

1594. Vocabula Grammaticae. Lugduni [Lyon]. [Second edition of the same title: 1626, 1758.]

1610. Syllabus Omnium Vocabulorum Grammaticae, Emmanuelis Alvari, de Societate Iesu, In nostram Vernaculam conuersorum cum Formis comparandi inflectendique nomina Adiectiua per omnes casus et genera. Quibus accesere componendi regulae et ortographia, ex Aldo Paulli F. et aliis in gratiam Latinae linguae tironum collecta. Augustae Vindelicorum [Augsburg]: Apud Chrysostomum Dabertzhofer. [Other editions of the same title: 1613, 1624, 1646, 1655, 1675, 1686, $1710,1714,1735$.

1644. Syllabus Vocabulorum Grammaticae Emmanuelis Alvari, de Societate Iesu, in nostram Vernaculam conuersorum: Cum Appendice: Generum, Declinationum et Prosodiae. Dilingae: Formis Academicis. [Other editions of the same title: $1654,1657,1660,1668,1701,1706,1708,1722,1725,1745,1751$.

9 This list has been compiled on the basis of bibliographic data available on the websites of many international libraries, as well as on the basis of either published, scanned entire copies or only cover pages of the Syllabus. It was not possible to cite the web addresses of all editions noted in the list, as this would exceed the length of the paper itself many times over. Second editions bearing the same title were not always published in the same city as the first cited edition. 
1681-1728. Syllabus Omnium Vocabulorum Grammaticae Emmanuelis Alvari, de Societate Jesu, in Italicam, et Germanicam Linguam conversorum: Generum, et Declinationum, et Prosodiae periculosioris ratione, in Nominibus: et in Verbis praeteritorum, et Supinorum terminatione adjecta. Editio postrema; Variis erroribus emendata. Tridenti: Ex Typographia Episcopali Joannis Paroni.

1713. Syllabus vocabulorum, grammaticae Emmanuelis Alvari, è Societate Jesu, In vernaculas: Hungaricam et Slavonicam conversorum, secundum Exemplar Viennense, paucis mutatis, nonnullis etiam additis. Tyrnaviae: Typis Academicis per Frid. Gall. [Other editions of the same title: 1717, 1731, 1733, 1759.]

1726. Syllabus Vocabulorum Grammaticae Emmanuelis Alvari è Societate Jesu: In Illyricam, sive Croatis et Sclavonibus vernaculam conversorum. Cum Appendice generum, declinationum. Zagrabiae: Impensis Joannis Michaëlis Schattner, Bibliopegi Zagrabiensi, Typis Joannis Bartholomaei Pallas. [21735, Zagreb: Typis Joannis Baptistae Weitz.]

1728. Syllabus vocabulorum, grammaticae Emmanuelis Alvari, è Societate Jesu, In vernaculas Hungaricam, Germanicam et Slavonicam conversorum. Cassoviae: Typis Academicis. [21770.]

1731. Syllabus vocabulorum, grammaticae Emmanuelis Alvari, è Societate Jesu, In vernaculas: Hungaricam et Germanicam linguam conversorum. Tyrnaviae: Typis Academicis per Frid. Gall. E. M. [Other editions of the same title: 1733, 1733, 1737, 1745, 1761, 1821, 1823, 1837.]

1742. Syllabus vocabulorum, grammaticae Emmanuelis Alvari, è Societate Jesu: In gratiam studiosae Juventutis separatim editus, cum interpretatione Germanica et Galica. Editio novissima. Bruntruti: s. 1.

1796. Syllabus vocabulorum Grammaticae Emmanuelis Alvari, in Croaticam linguam conversorum. Zagrabiae: Typis Novoszelianis. ${ }^{2} 1817$, Budae. Typis Regiae Universitatis. [It does not follow the tradition of previous editions of the Syllabus, rather, it is the original work of Tomaš Mikloušić.]

\section{Bibliography:}

Alvares, Emmanuel (1598). De institutione grammatica libri tres. Lugduni: Apud Abraham Cloquemin.

Alvares, Emmanuel (1859). De institutione grammatica libri tres: Juxta editionem Venetiam anni 1575. Parisiis: Excudebant Adrianus le Clere et soc.

Bratulić, Josip (1989). Juraj Habdelić: Život i djelo. In: Dictionar, ili Réchi Szlovenfzke zvexega ukup zebrane, u red pofztaulyene, i Diachkemi zlahkotene Trudom Jurja Habdelicha (pp 1-15). Zagreb: Kršćanska sadašnjost. [Talk over print.]

Carvalh, J. Vaz de (2001). Álvares (Alvares), Manuel (I). In: Charles E. O'Neill andJoaquín M. Domínguez (Eds.), Diccionario histórico de la Compañía de Jesús: Biográfico-temático: I: AA-Costa Rica. Madrid: Universidad Pontificia Comillas.

Cesarec, Ivan (2009). Tomaš Mikloušić (1767-1833): (Pregled života i književnog rada). Gazophylacium: Časopis za znanost, umjetnost, gospodarstvo i politiku, 14 (1-2), pp. 149-159.

Deželić, Velimir (1925). Biskupska a zatim Novoselska tiskara u Zagrebu (1794-1825). Narodna starina, 4(10), pp. 96-126. 
Dukat, Vladoje (1912). Habdelićev "Syllabus". Građa za povijest književnosti hrvatske, 7, pp. 101-105.

GHTC (s. a.). Padre Manuel Álvares - Gramática - edições completas ou parciais. In: Grupo de História e Teoria da Ciência. URL: http://www.ghtc.usp.br/server/Lusodat/ pri/02/pri02145.htm (01.05.2019.)

Horvat, Vladimir (1989). Juraj Habdelić među isusovačkim leksikografima. In: Dictionar, ili Réchi Szlovenfzke zvexega ukup zebrane, u red pofztaulyene, i Diachkemi zlahkotene Trudom Jurja Habdelicha (pp. 16-26). Zagreb: Kršćanska sadašnjost. [Talk over print.]

Jembrih, Alojz (2004). Hrvatskokajkavsko gramatičko nazivlje i leksička polivalencija u Mikloušićevu Syllabusu (1817). Učitelj, 4, pp. 35-51.

Jembrih, Alojz (2018). Gramatičko nazivlje i leksička polivalencija u Mikloušicevu Syllabusu (1817.). Kaj, 51, pp. 41-54.

Jochers, Christian Gottlieb; Adelung, Johann Christoph (1784). Fortzetzung und Ergänzungen zu Christian Gottlieb Jochers allgemeinem Gelibrifen-Lerico, worin die: Erster Band: $A$ und B (s. v. Alvarez, Emanuel, p. 667). Leipzig: in Johann Friedrich Bleditschens Dandlung.

Kemmler, Rolf (2015). The First Edition of the Ars Minor of Manuel Álvares' De institvtione grammatica libri tres (Lisbon, 1573). Historiographia Linguistica, 42(1), pp. $1-19$.

Machado, Diogo Barbosa (1752). Bibliotheca Lusitana Historica, Critica, e Cronologica: Tomo III (s. v. P. Manoel Alvares, pp. 170-172). Lisboa: Na Officina de Ignacio Rodrigues.

Mikloušić, Tomaš (1796). Syllabus vocabulorum Grammaticae Emmanuelis Alvari, in Croaticam linguam conversorum. Zagrabiae: Typis Novoszelianis.

Nemec, Krešimir (Ed.) (2000). Leksikon hrvatskih pisaca. Zagreb: Školska knjiga.

Ratio studiorum (1603). Ratio atque Institutio Studiorum Societatis Iesu. Turnoni: Apud Claudium Michaelem Typographum Uniuersitatis.

Syllabus (1610). Syllabus Omnium Vocabulorum Grammaticae, Emmanuelis Alvari, de Societate Iesu, In nostram Vernaculam conuersorum [...]. Augustae Vindelicorum: Apud Chrysostomum Dabertzhofer.

Syllabus (1726). Syllabus Vocabulorum Grammaticae Emmanuelis Alvari è Societate Jesu: In Illyricam, sive Croatis et Sclavonibus vernaculam conversorum. Cum Appendice generum, declinationum. Zagrabiae: Impensis Joannis Michaëlis Schattner, Bibliopegi Zagrabiensi, Typis Joannis Bartholomaei Pallas.

Šafařík, Paul Joseph (1865). Paul Jos. Šafařík's Geschichte der südslawischen Literatur: Aud dessen Handschiftichem Nachlasse herausgegeben von Josef Jiriček: II: Illirisches un kroatisches Schriftthum. Prag: Verlag von Friedrich Tempsky.

Vanino, Miroslav (1987). Isusovci i hrvatski narod II: Kolegiji dubrovački, riječki, varaždinski i požeški. Zagreb: Filozofsko-teološki institut Družbe Isusove. 
Isusovački Syllabus vocabulorum Alvaresove gramatike u hrvatskim izdanjima Ivana Kresnik*, Vladimir Horvat**

\section{Summary}

Godine 1572. objavljena je gramatika latinskoga jezika portugalskoga isusovca Manuela Alvaresa SJ (1526.-1582.) naslovljena De Institutione Grammaticae Libri Tres. Ta je gramatika 1599. u Ratio studiorum proglašena standardnim školskim priručnikom u isusovačkim školama. Njemački su isusovci za potrebe svojih đaka priredili posebni mali metodički priručnik koji pomaže u svladavanju jednoga težega poglavlja u Alvaresovoj gramatici, obrađujući problem roda i druge teže sadržaje gramatike. Najstariji takav priručnik objavljen je 1584. u Würzburgu pod naslovom Vocabula Grammaticae. Najstarije dostupno izdanje popisa riječi Alvaresove gramatike objavljeno je u Augsburgu 1610. godine: Syllabus Omnium Vocabulorum Grammaticae Emmanuelis Alvari. Iz njegova sadržaja vidljivo je da se odnosi na drugi dio prve knjige Alvaresove gramatike naslovljen De generibus nominum et declinationibus atque verborum praeteritis. U Syllabusu riječi nisu poredane abecednim redom, nego slijede metodiku nastave latinskoga jezika. Na njemačkom govornom području taj je priručnik bio izuzetno popularan i do kraja 18. stoljeća objavljen je u više desetaka izdanja. U 18. stoljeću priređene su verzije za druge jezike: mađarski i slovački (1713.), hrvatski (1726.), talijanski (1681.-1728.) i francuski (1742.), od kojih mnoge u više izdanja, uvijek poštujući izvorni koncept koji su osmislili njemački isusovci krajem 16. stoljeća. Hrvatskomu jeziku prilagodili su ga zagrebački isusovci te objavili 1726., i ponovo 1735. godine. Tu je prilagodbu mogao tehnički provesti bilo tko od isusovačkih patara te je jasno da to nitko od njih nije mogao potpisati kao svoje autorsko djelo. Godine 1796. pod naslovom Syllabus vocabulorum objavio je za hrvatski Tomaš Mikloušić svoj priručnik, koji ne slijedi izvornu ideju isusovačkoga Syllabusa, nego je Mikloušićev autorski metodički priručnik za svladavanje Alvaresove gramatike u cjelini. U radu se prvi puta daje popis svjetskih izdanja isusovačkoga priručnika Vocabula Grammaticae, odnosno Syllabus (Omnium) Vocabulorum Grammaticae Emmanuelis Alvari, do kojih su autori došli do objave rada.

Ključne riječi: Syllabus Vocabulorum; Vocabula Grammaticae; isusovačko školstvo; Manuel Alvares; Juraj Habdelić; Andrija Jambrešić; Tomaš Mikloušić

* Doc. dr. sc. Ivana Kresnik, Fakultet hrvatskih studija Sveučilišta u Zagrebu, Borongajska cesta 83d, 10000 Zagreb, Hrvatska. E-adresa: ikresnik@hrstud.hr

** Prof. dr. sc. Vladimir Horvat, profesor u miru, Fakultet filozofije i religijskih znanosti Sveučilišta u Zagrebu, Jordanovac 110, 10000 Zagreb, Hrvatska. E-adresa: vhorvat9@gmail.com 